\title{
Innovation for Sustainable Development in the Food Industry: Retro and Forward-Looking Innovation Approaches to Improve Quality and Healthiness
}

\begin{abstract}
Sustainable development in the food industry requires companies to be more innovative with their products and supply chain as a strategy for developing healthier and higher quality food products, and achieving better economic, environmental and social performance. A clear path to follow when companies decide to develop innovations for sustainability is still lacking, especially with a focus on quality and healthiness. This study analyses six case studies in the food industry in Italy, identifying two innovative approaches towards sustainable development for quality and healthiness, namely, forward-looking innovation and retro-innovation. The first one represents a typical business model redesign oriented to sustainability, i.e. developing new products and reconfiguring the supply chain processes for entering new market segments, applied mainly in smaller companies. The second one, indeed, implies a supply chain re-structuring strategy while going back to traditional agricultural processes, especially applied in companies with standard or certified products. Both approaches target sustainability performances and allow an improvement of food quality and healthiness.
\end{abstract}

Keywords: sustainable supply chain; food industry; innovation for sustainability; retro-innovation; sustainable development; quality and healthiness

\section{Introduction}

In the last decade, companies exhibited a growing adoption of sustainable practices aimed at enhancing performance in terms of economic, social and environmental aspects (Pullman et al., 2009; Cassells \& Lewis, 2011; Beske et al., 2014; Mzembe et al., 2016; Baumgartner, 2014).

To improve sustainability, companies rely on innovation levers to change current systems (Pullman \& Wu, 2012). Innovation theory and sustainability come together if firms adopt innovation to improve sustainability when pushed by external pressures or challenges (Kraatz \& Zajac, 1996; $\mathrm{Wu}, 2017)$. The theory explains how a rapid improvement of the results could be achieved when companies deal with pressures to innovate. New ventures and process or product innovations can have positive impacts on the environment, workers and consumers, and, at the same time, can lower production or transportation costs (Klewitz \& Hansen, 2014; Loucanova et al., 2015). 
The main types of innovations for sustainable development, namely, process, organization and product (Klewitz \& Hansen, 2014) are identified in the literature, but a clear assessment of the main innovative actions to take for achieving sustainability for each of these types is missing. Furthermore, it is important to mention that not all innovations for sustainability imply technological or conceptual breakthroughs; in some industries, the rediscovery of past procedures, knowledge and traditions involve innovation as well (Loucanova et al., 2015).

The food industry is particularly relevant for sustainable development as it can contribute to solving nutrition challenges in a growing global population, to helping conserve natural resources and to improving communities' well-being, while achieving competitive advantage (FAO, 2013; Klewitz \& Hansen, 2014; Chkanikova \& Mont, 2015; Mzembe et al., 2016). Food industry and sustainability both deal with product availability, company survival, consumer health and nutrition and community and country development (Fritz \& Schiefer, 2008; FAO, 2013; Pipatprapa et al., 2017). Hence, food companies' performance is not only based on economic dimensions but also on their environmental and social impacts (Pagell \& Wu, 2009; Pipatprapa et al., 2017; Fritz \& Shiefer, 2008), and innovation could be a winning strategy for achieving sustainability in this industry (Cassells \& Lewis, 2011; Klewitz \& Hansen, 2014). Innovation for sustainability has been mainly focused either on the environmental dimension only (Cassells \& Lewis, 2011; Zhu et al., 2012), or on the social dimension only (e.g. Marin et al., 2017), whereas a simultaneous focus on the entire triple bottom line is still scarce and is worth studying.

Besides the main sustainability pillars targeted with innovation for sustainability, it is also interesting to understand which specific objectives food companies pursue. Literature shows that quality and healthiness are key factors in many food companies' strategies (Krystallis et al., 2007; Chkanikova \& Mont, 2015). These attributes are able to boost competitiveness and, at the same time, drive the implementation of sustainability practices and innovation (Heikkurinen \& Forsman-Hugg, 2011). However, to the best of our knowledge, the link between quality and healthiness and innovations for sustainability in the food industry is under-investigated.

Thus, this study is aimed at identifying possible approaches to innovation for sustainability that leverage on food quality and healthiness, as well as determining how such approaches contribute to the company's sustainability performance metrics on the triple bottom line. The research is based on six case studies of the Italian food industry. In the following section, we review the literature on innovation for sustainable development in the food industry, and then we introduce the research questions, framework and methodology. Following, we will present and discuss the results and, finally, draw conclusions. 
Author's version of the article: in León-Bravo, V., Moretto, A., Cagliano, R., \& Caniato, F. (2019). "Innovation for sustainable development in the food industry: Retro and forward-looking innovation approaches to improve quality and healthiness".

Published in Corporate Social Responsibility and Environmental Management, 26(5), 1049-1062. DOI: 10.1002/csr.1785

\section{Innovation for Sustainable Development}

Recent literature has investigated the link between innovation and sustainability (Haanaes et al., 2011; Adams et al., 2015). Authors have proposed definitions, such as Charter \& Clark (2007, p. 9): 'Sustainable innovation is the process where sustainability considerations (environmental, social, and financial) are integrated into company systems from idea generation through to research and development and commercialization. This applies to product, services and technologies, as well as to new business and organizational models'. Similarly, the European Commission (EC, 2008) has defined it as: 'the production, assimilation or exploitation of a novelty in products, production processes, services or in management and business methods, which aims, throughout its lifecycle, to prevent or substantially reduce environmental risk, pollution and other negative impacts of resource use'.

Regarding the degree of innovation, some authors stated that innovation for sustainability requires radical innovation because sustainable development aims at transforming a large part of the production and consumption systems (Boons, 2009), and that incremental innovation is not sufficient to achieve an optimal global system configuration (Wagner, 2012). Other authors argue that simply modifying products and processes is not sufficient. They contend that companies also need to modify the ways they produce value, capture value and deliver value to consumers and that this involves the overall network of stakeholders (Formentini \& Taticchi, 2016; Schaltegger et al., 2016). This literature stream thus suggests business model innovations for sustainability (Beattie \& Smith, 2013; Bocken et al., 2014) as a way to change 'the way you do business' rather than 'what you do'.

Mainly two streams investigate the scope and content of the innovations for sustainability: product innovation and supply chain innovation. The first one studies the changes in product design, also known as eco-design, or design for sustainability, considering product architecture, materials, recyclability, durability and longevity, label, package and origin (e.g. fair-trade and organic). These innovations are applied either in an existing product (product improvement) or in a totally new concept (new product development) (Klewitz \& Hansen, 2014). Moreover, regarding packaging, reduction of raw material consumption, design for disassembly, remanufacturing or recycling involve innovative practices for sustainability, as well (Bocken et al., 2014; Klewitz \& Hansen, 2014). The second stream of literature, referring to supply chain innovation, encompasses innovations in supply chain configuration (i.e. redesign or changes in the supply chain) (Goodman, 2004; Maloni \& Brown, 2006), supply chain processes (e.g. eco-efficiency innovations, waste handling, logistics, packaging and sourcing) (Catarino et al., 2007; Pagell \& Wu, 2009; van der Vorst et al., 2000; Cassells \& Lewis, 2011; Zhu et al., 2012; Bocken et al., 2014; Klewitz \& Hansen, 2014), and supply chain monitoring 
Author's version of the article: in León-Bravo, V., Moretto, A., Cagliano, R., \& Caniato, F. (2019). "Innovation for sustainable development in the food industry: Retro and forward-looking innovation approaches to improve quality and healthiness". Published in Corporate Social Responsibility and Environmental Management, 26(5), 1049-1062. DOI: 10.1002/csr.1785

and control (e.g., overseeing the supply chain partners' conformity to sustainability expectations and agreements) (Golan et al., 2004; Beske \& Seuring, 2014).

Furthermore, most of the literature implies innovation should be radical, but other studies also noted that not all the innovative practices implemented for sustainability imply technological or conceptual breakthroughs. For instance, Castellano et al. (2013) identified some industries where the concept of innovation is linked to heritage, tradition, nostalgia and revival, which are called retroindustries. In these industries, rediscovering and bringing back procedures, knowledge and traditions from the past involve innovation as well (Loucanova et al. 2015). In line with this concept, Chunduri (2013) mentioned three different approaches for retro-innovation: 1. mimicking a product or experience of the past; 2. innovations as a nostalgic form to meet a new need; and 3. use of a new format to meet an old need. This retro-innovation approach is said to be appealing to consumers as they already know the product or service, and it is attractive to companies as less capital is needed, costs can be reduced, and quicker investment recovery can be achieved, thereby enhancing economic sustainability (Loucanova et al. 2015). Some authors (Brown, 1999; Brown et al., 2003) also mentioned the value of this kind of innovation to create a strong alliance with consumers. Marsden and Smith (2005) mentioned the importance of this concept, especially for ecological entrepreneurship, as a way to achieve sustainable development in local communities through a higher focus on food quality. Despite the relevance of this perspective, the concept of retro-innovation is still under-investigated, especially for what concerns non-agricultural companies (Cagliano et al., 2017).

The need to study innovation for sustainability in the food industry arises from the relationship of this industry with products availability, companies' survival, consumers' health and nutrition, communities and countries development (Fritz \& Schiefer, 2008), and thus the constant search for quality and healthiness in this sector. The processes in the food industry generate important impacts not only on the environment but also on communities (Beske et al. 2014; Fritz \& Schiefer, 2008; Pipatprapa et al. 2017; Pullman et al. 2009). Modern food consumption habits increase the demand of certain products such as meat, sugar and fats, with consequent impact on the production stages and above all, on consumer's health (European Commission, 2014). Hence, as different authors argued, a firm's performance is not only influenced by the quality of its product but also by its environmental and social responsibility (Pipatprapa et al. 2017; Cassells \& Lewis, 2011; Jhonson, 2015; Beske \& Seuring, 2014). Authors propose several performance areas to be taken into account in the food industry: environmental performances (e.g., emissions, water usage, waste, energy, natural resources usage), social responsibility (e.g., community's wealth and well-being, employees' welfare, 
consumer health) and, economic benefits (e.g., efficiency, access to new markets and consumers) (European Commission, 2014; Pagell \& Wu, 2009; Baumgartner, 2014; Fritz \& Schiefer, 2008; Johnson, 2015; Zhu et al., 2012). In spite of that, clear links between different sustainability innovations implemented to improve quality and healthiness and, the impact on performances are missing in existing literature.

\section{Research Questions and Framework}

The role of quality and healthiness as key drivers for consumer choice and for driving sustainability strategies is discussed in the literature (e.g. Trienekens \& Zuurbier, 2008; Szocs \& Lefebvre, 2016). However, the role of innovation for sustainability to improve food quality and healthiness is scarcely studied. Hence, the aim of this study is to identify possible approaches to innovation for sustainability to improve food quality and healthiness, as stated in the first research question:

RQ1: What approaches to innovation can be used to pursue a sustainability strategy oriented to food quality and healthiness?

On the other hand, it is important to consider that sustainability represents a challenge in the food industry as different pressures and expectations exist and, companies are urged to implement practices that reduce the negative effects for the planet and the people (Fritz \& Schiefer, 2008; Hartmann, 2011; Pipatprapa et al, 2017). Most of the literature about innovation for sustainability mainly considers the environmental impact (e.g. Beise \& Rennings, 2005), with a major lack in respect to the social impact. Nevertheless, the literature about sustainability addresses the importance of having a triple bottom line approach to measure the impact of sustainability strategies (Elkington, 1998; Heikkurinen \& Forsman-Hugg, 2011). We aim at studying the sustainability impact in terms of performance targeted when implementing innovations for sustainability oriented to food quality and healthiness. Thus, we propose our second research question:

RQ2: What sustainability performance dimensions (i.e. environmental, social and economic) are targeted by innovations used to pursue a sustainability strategy oriented to food quality and healthiness?

Figure 1 describes the research framework that summarizes the key research constructs and the research questions. 


\section{Research Methodology}

The phenomenon under study in this paper needs exploration through a variety of lenses, helping the identification and understanding of multiple facets; therefore, the multiple case study methodology is adopted (Baxter \& Jack, 2008; Yin, 2008). The main advantage of multiple case studies is the robustness and reliability that this type of study can obtain, by analyzing multiple and rich data sources and, thus, enhancing data reliability. This approach will enable us to explore differences and commonalities among cases, and to recognize if patterns of relationships among constructs within and across cases exist (Eisenhardt \& Graebner, 2007; Baxter \& Jack, 2008).

The choice of an appropriate set of cases contributes to the control of potential external variation, and supports the definition of the limits for the generalization of outcomes (Eisenhardt \& Graebner, 2007). Specifically, the cases in this study are firms that integrated sustainability into their strategy and included it in their business models by developing a culture of respect for the environment and society. Moreover, cases selected had a clear focus on quality and healthiness.

The cases were selected with the goal to be representative of the industry and adequate to the study. The sample includes Italian companies of different sizes which have different levels of vertical integration and deal with different type of products (e.g. fresh, processed, conserved and frozen food), including the main product categories, considering high perishable and less perishable products, certified and non-certified products, animal and vegetal origin. All the companies sell products both under their brand and as a private label for retailers. Companies - that operate in different parts of the country - were selected for convenience and also because of the relevance of Italy in the worldwide food market. These firms exhibited their commitment towards sustainability in their mission and vision, but also in terms of practices adopted, the publication of sustainability reports and the existence of a specific role in the company, which is directly involved in the management of sustainability.

As unit of analysis, we selected the product line, because projects of innovation for sustainability are generally performed at the product line level. Thus, given that Case E has two different product lines, the complete sample involves six units of analysis. The characteristics of the sample are summarized in Table 1. 
Multiple data sources were accessed, such as interviews, observations, archival sources and plant visits, adding strength to the findings while carefully managing and analyzing the data. (Baxter \& Jack, 2008; Yin, 2008). Semi-structured interviews in person or by phone were conducted with representatives of all companies between April and October 2015. At least two interviews were conducted in each company; moreover, data were triangulated through company visits (in company $\mathrm{B}$ and E) as well as through secondary data provided by the company or found by the authors. The interviews involved quality managers, technical managers, marketing managers, CEOs and/or company owners, and the interviews were conducted by at least two researchers. More than one manager was simultaneously involved in several interviews. A preliminary interview protocol was prepared based on information from literature; then, it was updated and adapted considering the specificities of each case. The questions answered during the interviews were related to: the company's sustainable development conceptualization; the analysis of the impact of sustainable innovations on the company's business models; the sustainable innovations implemented; the identification of which of those innovations were implemented with the purpose of increasing product quality and healthiness; and the sustainability performances targeted. Before proceeding with the interview, a preliminary collection of publicly available information was conducted to gain internal validity (Yin, 2008). Finally, triangulation of data was also performed by means of direct observation during company visits (Baxter \& Jack, 2008; Yin, 2008).

Data collected were then transcribed and organized in order to create a case database and to preserve the chain of evidence. Several researchers were involved in the different data collection and data analysis phases, as a way to reduce individual bias and validate information during the process. Appendix A describes the coding of the innovations for sustainability. The analysis of the information was first performed within each case, and then with the cross-case method in a consecutive step. The within-case analysis involved the identification of sustainable innovations implemented within the categories mentioned in Appendix A. First, the authors aimed at understanding if sustainable innovations are actually driven by quality and healthiness. Moreover, the within-case analysis described the sustainability performance metrics targeted in the triple bottom line: environmental, social and economic dimensions, the challenges and the future steps. Once the information was organized and completed, a preliminary report was shared with the interviewees in order to obtain feedback and validation. The cross-case analysis (see Appendix B.1 and B.2 and Appendix C) refers to the comparison of variables among the cases in order to identify commonalities and differences and to determine if patterns exist. 


\section{Two Approaches to Innovation for Sustainable Development}

Through the within- and the cross-case analyses, two main approaches to innovation for sustainable development were identified, consistently with the indication of literature (Loucanova et al. 2015; Klewitz \& Hansen, 2014), as summarized in Table 2. We identified several innovations for sustainability deployed by the companies in our sample and we classified them in two categories according to their relation to quality and healthiness. First, there were innovations 'specifically driven by quality and healthiness', e.g. short supply chain (SC) design for ensuring high-quality raw materials. Second, there were innovations 'enabling the achievement of quality and healthiness', e.g. tracking and traceability systems that help in monitoring product quality along the chain. The two approaches to innovation for sustainability are characterized by a different combination of such innovations.

\section{TABLE 2 HERE-}

\section{The Forward-looking Innovation Approach: Business Model Redesign}

The forward-looking innovation approach is defined considering the strategies in Cases D and $\mathrm{E}^{2}$. Innovation for sustainability in these companies means to revise their recipes and/or to include more complex products with an overall rethinking of the business model. In these cases, the product was changed with the introduction of new raw materials that, in turn, allowed to access new markets and customers. New technologies are used to identify and test new recipes, looking for innovative solutions and tastes.

However, these companies also mentioned that product innovation alone was not sufficient, if it was not consistent with innovations in their supply chain. A new supply chain configuration was seen as necessary, and was usually accomplished by introducing new suppliers or setting up short supply chains. For instance, Case $\mathrm{E}^{2}$ had to scout new suppliers, as soybeans had not been used in the past for frozen, ready-to-eat, protein-based products at all. In addition, these companies focused on purchasing and supply management innovation (i.e. supplier auditing, selection and collaboration) and on logistics and retail management. For example, Case D chose to work with suppliers affiliated with the World Fair Trade Organization (WFTO), or with organizations that were capable of organizing, managing and certifying chains, as well as prioritizing fair relations with producers. In this way, the company was able to access the appropriate raw material for its new products, guaranteeing quality and healthiness features. Finally, the innovative business model is obtained 
thanks to an appropriate support of new technologies, used to make processes and activities as smooth as possible, as an enabling factor.

Companies adopting this approach, Case $\mathrm{D}$ and $\mathrm{E}^{2}$, have the clear goal to follow an existing market trend to reinforce their market position or to improve their marginality in some niches. The main advantage of this model is the possibility to be used either in small companies or in companies lacking a strong brand. The success of this approach stems from the ability to collaborate with external partners and to sell their products through different channels and to different customers, as well as to communicate their commitment to sustainability. For instance, for these companies, packaging provides an opportunity to display their engagement messages. Hence, packaging innovation is also a communication tool, to link the consumer with the value of the product and the value of a healthier life style.

Considering Research Question 2, the forward-looking innovation approach targets a triple bottom line performance. Regarding economic sustainability, the focus on quality improvement is fundamental for achieving higher revenues when entering into new markets and market segments and for attracting new consumers. When new products are developed with this approach, companies demonstrate wider sustainability attention, including environmental impact by minimizing waste, emissions, water consumption, resources usage etc. Additionally, attention to social sustainability is demonstrated with initiatives oriented to encourage consumers to take better care of their health, developing not only healthier products but also products adapted for specific health conditions.

This approach is found primarily in small and medium companies that are flexible enough for conceptualizing a breakthrough product innovation (Moore \& Manring, 2009) and that embrace this approach to differentiate themselves from large-scale players by targeting market niches. Secondly, this approach is feasible for companies where the product is not constrained by specific regulations or certification schemes (e.g. PDO or PGI).

This model of innovation is quite aligned with the indications provided by the literature, because the main characteristic is the introduction of brand new products with a clear sustainability focus, with a renewed quality and healthiness-oriented strategy. The cases highlighted the desire to modify the business model; an approach that is consistent with Moresi et al. (2008) who identified food companies that are willing to introduce a 'care-oriented business'.

Cases also highlighted some drawbacks of this approach. Companies opting for a forward-looking innovation approach base their strategy on new product development, however they face the challenge of continuously innovating to maintain their leading positioning. Even if companies 
Author's version of the article: in León-Bravo, V., Moretto, A., Cagliano, R., \& Caniato, F. (2019). "Innovation for sustainable development in the food industry: Retro and forward-looking innovation approaches to improve quality and healthiness".

Published in Corporate Social Responsibility and Environmental Management, 26(5), 1049-1062. DOI: 10.1002/csr.1785

succeed in the market with their current innovations, they will be compelled to keep attracting their customers with novel products, which in turn imply the need to allocate important resources to it. Being mainly smaller companies adopting this approach, such challenges are not easy to face.

\section{The Retro-innovation Approach: Back to Basic Principles}

The retro-innovation approach was defined considering the strategies in Cases A, B, C and $\mathrm{E}^{1}$. The word "retro" derives from Latin and means "backwards, behind", but also "formerly, in past times" and these are exactly the main keywords of this approach. This approach is totally opposite to the previous one because the goal is to preserve exactly the same traditional product, or perform just minimal changes, through exactly the same business model, while pursuing new methods to achieve sustainable development, and improving quality and healthiness. The focus in these cases was to recover traditional processes, to revise agricultural techniques for restoring tradition and ancient values, as Case A did, and to rediscover the quality and healthiness of original products, i.e. to move back to old traditions for achieving sustainability. In these cases, the companies revised production methods that minimized chemicals' use and strengthened the entire production process control, all consistent with traditional environmental conservation and food safety objectives. For instance, Case A installed a system to recover rainwater, and dedicated another area for composting. Additionally, the supply chain configuration and supply chain processes were revised, moving back to basic agriculture as in Cases $\mathrm{A}$ and $\mathrm{E}^{1}$. For example, Case $\mathrm{E}^{1}$ incorporated new certified suppliers to its organic meat products supply chain.

Furthermore, companies in this retro-innovation approach focused on revising traditional agricultural techniques through improved technology, while supporting small and local farmers and improving animal welfare too. Concerning the latter, Case B created an integrated supply chain, implementing a complete cycle from chick to finished product, e.g. portioned-packed chicken, caring for the chick's wellbeing, thanks to the support of technology. In this way, it was possible to fully monitor and control all the steps of the chain to guarantee quality and animal welfare. Regarding technology implementation, for example, Case C set up, in 2005, a collaboration plan with a longstanding traditional company that specialized in machinery production for olive oil milling. The project intended to embrace the techniques inherited from the family's experience and combine them with modern technological innovation. Another example is Case A that used electric machines for harvesting, and set up a depuration and sanitizing plant to better ensure product quality and safety.

The 'back-to-roots' strategies were also observed in packaging and communication. Whether in the forward-looking model the purpose of communication was to present the innovativeness of the 
product and business model, companies adopting the retro-innovation approach need to transmit their values and the related heritage, showing their ability to maintain the same quality level of the origin, also thorough innovative and efficient processes. For example, Case $\mathrm{C}$ produces unfiltered extra virgin olive oil, and, the packaging and communication strategies enhance the value of the oil's characteristics. Similarly, Case $\mathrm{E}^{1}$ advertises the benefits of its organic products in the packaging; and Case A promotes the health and safety certifications of its products in the website and packaging.

On the other hand, these companies introduced modifications at product level mainly in terms of packaging or using organic components for some small product modifications. This approach is also driven by compliance with regulations. For instance, in Case C, certified products such as PDO or PGI cannot be altered, because the real value of the product is in the traditional practices and ingredient preservation.

Companies in this approach clearly addressed that, thanks to the shift back to old principles, they could recover a competitive advantage in respect to their competitors. Companies with certified products, that usually considered innovation very challenging because of the strict regulations, found this retro-innovation approach aligned with their strategy and proved to bring the benefits expected.

Addressing Research Question 2 that intends to identify the performance dimensions targeted, these retro-innovations aim at improvements in a triple bottom line perspective and this is one of the strengths of this approach. For economic performance, the focus is on efficiency and resource optimization. In addition, improvement in economic performance is achieved, thanks to a higher quality product for which the consumer is willing to pay a premium price. A differentiation strategy with the retro-innovation approach is implemented, as companies attempt to satisfy end-consumers and retailers that clearly search for high-quality products and a controlled origin. On the other hand, for environmental performance, companies in the retro-innovation approach focus on emission reduction, efficient energy use, and waste reduction. As in Case C: 'We created a composting center in which we recycle all waste we produce, then turning it into fertilizer for plants'. Therefore, the company intends to reduce waste and emissions while paying attention to manufacturing processes. A similar strategy is presented in Case A with the composting, sanitization, and photovoltaic roofs implemented. In terms of social sustainability in the retro-innovation approach, the main impact was achieved by promoting healthier diets with higher quality products.

The novelty of this approach was that the firms found new managerial approaches for implementing, on a manufacturing scale, with renewed technology, traditional artisanal and agricultural principles. Thus, the innovation also involved transferring traditional concepts, highly valued by consumers, into large-scale production complemented with investments in technological 
innovations. This approach is consistent with the existing literature addressing that retro-innovation may become a competitive tool in global markets because of the feasibility of faster development, known business environment and sustainable resource usage (Loucanova et al., 2015). Nonetheless, interviews highlighted that companies in the retro-innovation approach face several challenges too, firstly, as other companies in the market start adopting this kind of strategy and the differentiation obtained so far would dilute in time. Hence, continuous improvement becomes crucial for these companies, they need to keep investing in their product and supply chain innovations, e.g., reducing waste and emissions, in order to maintain and improve their performance and appeal in the market. However, continuous investment becomes a challenge for smaller companies with fewer resources (Johnson, 2015).

\section{Conclusions}

Considering the intersection of sustainability and innovation for food companies, this paper aimed at 1) analyzing and identifying the different approaches to innovations for sustainability aimed to improve quality and healthiness, and, 2) identifying the performances targeted in a triple bottom line perspective when implementing innovations for sustainability, considering that improving food quality and healthiness are two priorities for managers in the industry and new sources of innovations are key assets for that purpose. Certainly, each innovation needs to be evaluated in terms of performance and this research supports managers in identifying impacts with a triple bottom-line perspective.

Based on the analysis of six cases in Italy, we identified two different approaches to innovation for sustainability for the first research question. A forward-looking innovation approach, oriented to the development of a new business model based entirely on sustainability. This approach is pursuable also by small and medium companies free from product certification constraints, similar to those presented in the literature for other industries. And a retro-innovation approach (Loucanova et al., 2015), oriented to returning to the implementation of traditional procedures but at an industrial scale, adequate also for large companies and certified products. Regarding the second research question, both approaches target a triple bottom line performance when implementing their sustainable innovation strategy, demonstrating the value for all the pillars of sustainability.

Although exploratory, this paper provides some relevant contributions to research. First, this paper shed some light on the topic of innovation for sustainable development in the food industry by proposing two different approaches for improving sustainability driven by quality and healthiness, a key driver in this industry. The paper also identifies the links between sustainable innovation choices 
with triple bottom line performance objectives, showing the relevance of innovation not only for environmental performance but also for social and economic performances. Finally, the paper blends different types of innovation for sustainability - product and supply chain - within a specific context of investigation, which is highly relevant from a sustainability perspective given the inherent sustainability challenges that food industry deals with.

The results in this study are relevant for managers, as well. When a company in the food industry intends to develop an innovative sustainability strategy, managers need to select the most suitable approach according to the firm's objectives and capabilities while targeting product quality and healthiness. Both approaches could be adopted in small, medium and large companies. Moreover, companies intending to develop innovations for sustainability would aim at generating some kind of benefits, in terms of sustainability performances. The paper addresses the potential positive sustainability performance impacts when opting for any of the two approaches, helping managers to target the areas of potential improvements achieved through innovations for sustainability. The paper also supports managers to be aware of the main challenges of each of the two models.

Some future developments can be identified as well, linked to the main limitations of the paper. First, it might be relevant to validate these results with a broader sample, in order to confirm the two approaches and to prove the link between adoption of practices and improvement of performance. Secondly, results might be extended to other drivers beyond quality and healthiness.

\section{References}

Adams R, Jeanrenaud S, Bessant J, Denyer D, Overy P. 2015. Sustainability - oriented innovation: A systematic review. International Journal of Management Reviews 18(2): 180-205.

Appelqvist, P., Lehtonen, J. M., \& Kokkonen, J. 2004. Modelling in product and supply chain design: literature survey and case study. Journal of Manufacturing Technology Management, 15(7): 675-686.

Baumgartner R. J. 2014. Managing corporate sustainability and CSR: A conceptual framework combining values, strategies and instruments contributing to sustainable development. Corporate Social Responsibility and Environmental Management 21(5), 258-271.

Baxter P, Jack S. 2008. Qualitative case study methodology: Study design and implementation for novice researchers. The Qualitative Report 13(4): 544-559.

Beattie V, Smith SJ. 2013. Value creation and business models: Refocusing the intellectual capital debate. The British Accounting Review 45(4): 243-254. http://dx.doi.org/10.1016/j.bar.2013.06.001

Beise, M., \& Rennings, K. 2005. Lead markets and regulation: a framework for analyzing the international diffusion of environmental innovations. Ecological economics, 52(1): 5-17.

Beske P, Land A, Seuring S. 2014. Sustainable supply chain management practices and dynamic capabilities in the food industry: A critical analysis of the literature. International Journal of Production Economics 152: 131-143. 
Author's version of the article: in León-Bravo, V., Moretto, A., Cagliano, R., \& Caniato, F. (2019). "Innovation for sustainable development in the food industry: Retro and forward-looking innovation approaches to improve quality and healthiness". Published in Corporate Social Responsibility and Environmental Management, 26(5), 1049-1062. DOI: 10.1002/csr.1785

Bocken NMP, Farracho M, Bosworth R, Kemp R. 2014. The front-end of eco-innovation for eco-innovative small and medium sized companies. Journal of Engineering and Technology Management 31: 43-57.

Boons, F., Montalvo, C., Quist, J., \& Wagner, M. 2013. Sustainable innovation, business models and economic performance: an overview. Journal of Cleaner Production, 45: 1-8.

Brown S. 1999. Retro-marketing: Yesterday's tomorrows, today! Marketing Intelligence \& Planning 17(7): 363-376.

Brown S, Kozinets RV, Sherry Jr JF. 2003. Teaching old brands new tricks: Retro branding and the revival of brand meaning. Journal of Marketing 67(3): 19-33.

Cagliano R, Worley CG, Caniato FF. 2016. The challenge of sustainable innovation in agri-food supply chains. In Organizing Supply Chain Processes for Sustainable Innovation in the Agri-Food Industry. Ed Cagliano R, Caniato F, Worley CG. (pp. 1-30). Emerald Group Publishing Limited.

Cassells S, Lewis K. 2011. SMEs and environmental responsibility: Do actions reflect attitudes? Corporate Social Responsibility and Environmental Management 18(3): 186-199.

Castellano S, Ivanova O, Adnane M, Safraou I, Schiavone F. 2013. Back to the future: Adoption and diffusion of innovation in retro-industries. European Journal of Innovation Management 16(4): 385-404.

Catarino, J., Mendonça, E., Picado, A., Anselmo, A., da Costa, J. N., Partidário, P. 2007. Getting value from wastewater: by-products recovery in a potato chips industry. Journal of Cleaner Production, 15(10): 927931.

Charter, M., Clark, T. (2007). Sustainable innovation: Key conclusions from sustainable innovation conferences 2003-2006 organised by the Centre for Sustainable Design.

Chkanikova O, Mont O. 2015. Corporate supply chain responsibility: Drivers and barriers for sustainable food retailing. Corporate Social Responsibility and Environmental Management 22(2): 65-82.

Chunduri CH. 2013. Marketing nostalgia - Retro innovation (on-line). https://medium.com/noisebranded/b542fbbe406e [16 September 2015].

Earle, M. D. 1997. Changes in the food product development process. Trends in Food Science \& Technology, 8(1): 19-24.

Eisenhardt Graebner ME. 2007. Theory building from cases: Opportunities and challenges. Academy of Management Journal 50(1): 25-32.

Elkington J. 1998. Partnerships from cannibals with forks: The triple bottom line of 21st - century business. Environmental Quality Management 8(1): 37-51.

European Commission, Agricultural and Rural Development. 2014. The EU's common agricultural policy (CAP): for our food, for our countryside, for our environment. http://ec.europa.eu/agriculture/capoverview/2014 en.pdf [November 2015]

European Commission (EC), 2008. Call for proposals under the Eco-innovation 2008 programme. DG Environment. http://ec.europa.eu/environment/etap/ecoinnovation/library en.htm. [September 2017].

Food and Agricultural Organization of the United Nations (FAO). 2013. The state of food and agriculture. http://www.fao.org/publications/sofa/2013/en/ [November 2015].

Formentini M, Taticchi P. 2016. Corporate sustainability approaches and governance mechanisms in sustainable supply chain management. Journal of Cleaner Production 112: 1920-1933.

Fritz M, Schiefer G. 2008. Food chain management for sustainable food system development: A European research agenda. Agribusiness 24: 440-452. doi: 10.1002/agr.20172

Golan, E. H., Krissoff, B., Kuchler, F., Calvin, L., Nelson, K., \& Price, G. 2004. Traceability in the US food supply: economic theory and industry studies (No. 33939). United States Department of Agriculture, Economic Research Service.

Gold S, Seuring S, Beske P. 2010. The constructs of sustainable supply chain management-A content analysis based on published case studies. Progress in Industrial Ecology. An International Journal 7(2): $114-137$. 
Author's version of the article: in León-Bravo, V., Moretto, A., Cagliano, R., \& Caniato, F. (2019). "Innovation for sustainable development in the food industry: Retro and forward-looking innovation approaches to improve quality and healthiness". Published in Corporate Social Responsibility and Environmental Management, 26(5), 1049-1062. DOI: 10.1002/csr.1785

Goodman, D. 2004. Rural Europe redux? Reflections on alternative agro-food networks and paradigm change. Sociologia ruralis, 44(1): 3-16.

Haanaes K, Arthur D, Balagopal B, Kong MT, Velken I, Hopkins MS. 2011. First look: The second annual sustainability \& innovation survey. MIT Sloan Management Review 52(2): 77.

Heikkurinen, P., \& Forsman - Hugg, S. 2011. Strategic corporate responsibility in the food chain. Corporate Social Responsibility and Environmental Management, 18(5), 306-316.

Ilbery, B., \& Maye, D. 2005. Food supply chains and sustainability: evidence from specialist food producers in the Scottish/English borders. Land Use Policy, 22(4): 331-344.

Johnson M. P. 2015. Sustainability management and small and medium - sized enterprises: Managers' awareness and implementation of innovative tools. Corporate Social Responsibility and Environmental Management 22(5), 271-285.

Klewitz J, Hansen EG 2014. Sustainability-oriented innovation of SMEs: A systematic review. Journal of Cleaner Production 65: 57-75.

Kraatz MS, Zajac EJ. 1996. Exploring the limits of the new institutionalism: The causes and consequences of illegitimate organizational change. American Sociological Review: 812-836.

Krystallis, A., Chryssochoidis, G., \& Scholderer, J. 2007. Consumer-perceived quality in 'traditional'food chains: The case of the Greek meat supply chain. Appetite, 48(1), 54-68.

Loucanova E, Parobek J, Kalamarova M. 2015. Retro-innovation and corporate social responsibility. Studia Universitatis 'Vasile Goldis' Arad-Economics Series 25(4): 1-10.

Maloni MJ, Brown ME. 2006. Corporate social responsibility in the supply chain: An application in the food industry. Journal of Business Ethics 68(1): 35-52.

Marin L, Martín PJ, Rubio A. 2017. Doing good and different! The mediation effect of innovation and investment on the influence of CSR on competitiveness. Corporate Social Responsibility and Environmental Management 24(2): 159-171.

Marsden T, Smith E. 2005. Ecological entrepreneurship: Sustainable development in local communities through quality food production and local branding. Geoforum 36(4): 440-451.

Moore SB, Manring SL. 2009. Strategy development in small and medium sized enterprises for sustainability and increased value creation. Journal of Cleaner Production 17(2): 276-282.

Moresi M, Masi P, Massini R. 2008. Industria Alimentare Italiana: Quali prospettive di ricerca e sviluppo? Società Italiana di Scienze e Tecnologie Alimentari (SISTAL). http://www.sistal.org/allegati/2_RELAZSISTAL-ISMEA.pdf [September 2016]

Mzembe AN, Lindgreen A, Maon F, Vanhamme J. 2016. Investigating the drivers of corporate social responsibility in the global tea supply chain: A case study of Eastern Produce Limited in Malawi. Corporate Social Responsibility and Environmental Management 23(3): 165-178.

Pagell M, Wu Z. 2009. Building a more complete theory of sustainable supply chain management using case studies of 10 exemplars. Journal of Supply Chain Management 45(2): 37-56.

Pipatprapa A, Huang H, Huang C. H. 2017. The role of quality management \& innovativeness on green performance. Corporate Social Responsibility and Environmental Management 24(3), 249-260.

Pullman ME, Maloni MJ., Carter CR. 2009. Food for thought: Social versus environmental sustainability practices and performance outcomes. Journal of Supply Chain Management 45(4): 38-54.

Pullman M, Wu Z. (2012). Food Supply Chain Management: Economic, Social and Environmental Perspectives. Routledge.

Schaltegger S, Hansen EG, Lüdeke-Freund F. 2016. Business models for sustainability: Origins, present research, and future avenues. Organization \& Environment 29(1): 3-10.

Szocs, C., \& Lefebvre, S. 2016. The blender effect: physical state of food influences healthiness perceptions and consumption decisions. Food Quality and Preference, 54: 152-159. 
Trienekens, J., \& Zuurbier, P. 2008. Quality and safety standards in the food industry, developments and challenges. International Journal of Production Economics, 113(1): 107-122.

United Nations (UN), 2015. Millenium development goals and beyond 2015. http://www.un.org/millenniumgoals/povertgy.shtml [September, 2016]

Vachon S, Klassen RD. 2008. Environmental management and manufacturing performance: The role of collaboration in the supply chain. International Journal of Production Economics 111(2), 299-315. van der Vorst JG. 2000. Effective Food Supply Chains: Generating, Modelling and Evaluating Supply Chain Scenarios. Landbouwuniversiteit Wageningen (Wageningen Agricultural University).

Wagner, M. (2012). Ventures for the public good and entrepreneurial intentions: An empirical analysis of sustainability orientation as a determining factor. Journal of Small Business \& Entrepreneurship, 25(4): 519-531.

Wu GC. 2017. Effects of socially responsible supplier development and sustainability-oriented innovation on sustainable development: Empirical evidence from SMEs. Corporate Social Responsibility and Environmental Management 24(6): 661-675.

Yin RK. 2008. Case Study Research: Design and Methods. 4th Ed. Sage Publications: Thousand Oaks, CA. Zhu, Q., Sarkis, J., Lai, K. H. 2012. Examining the effects of green supply chain management practices and their mediations on performance improvements. International Journal of Production Research, 50(5): 1377-1394.

\begin{tabular}{|c|c|c|c|c|c|c|}
\hline Company & $\mathbf{A}$ & B & $\mathbf{C}$ & D & \multicolumn{2}{|c|}{$\mathbf{E}$} \\
\hline $\begin{array}{l}\text { Revenues } \\
2016\end{array}$ & $14 \mathrm{Mln} €$ & $325 \mathrm{M} \ln €$ & $144 \mathrm{M} \ln €$ & 12.9 Mln $€$ & \multicolumn{2}{|c|}{ 9.7 Mln $€$} \\
\hline Location & $\begin{array}{l}\text { Campania } \\
\text { region } \\
\text { (South Italy) }\end{array}$ & $\begin{array}{l}\text { Marche region } \\
\text { (Center Italy) }\end{array}$ & $\begin{array}{l}\text { Umbria region } \\
\text { (Center Italy) }\end{array}$ & $\begin{array}{c}\text { Veneto region } \\
\text { (Northeast Italy) }\end{array}$ & \multicolumn{2}{|c|}{$\begin{array}{l}\text { Lombardia region } \\
\text { (North Italy) }\end{array}$} \\
\hline $\begin{array}{l}\text { Main } \\
\text { processes }\end{array}$ & $\begin{array}{l}\text { Growing, } \\
\text { processing, } \\
\text { packaging, } \\
\text { distribution }\end{array}$ & $\begin{array}{l}\text { Breeding, } \\
\text { processing, } \\
\text { packaging, } \\
\text { distribution }\end{array}$ & $\begin{array}{l}\text { Growing, } \\
\text { processing, } \\
\text { packaging }\end{array}$ & $\begin{array}{c}\text { Processing, } \\
\text { packaging }\end{array}$ & \multicolumn{2}{|c|}{$\begin{array}{c}\text { Processing, } \\
\text { packaging }\end{array}$} \\
\hline $\begin{array}{l}\text { Core } \\
\text { business } \\
\text { lines }\end{array}$ & $\begin{array}{c}\text { Fresh } \\
\text { vegetables }\end{array}$ & Poultry & Olive oil & $\begin{array}{l}\text { Gluten free } \\
\text { bakery/ } \\
\text { confectionery }\end{array}$ & $\begin{array}{c}\text { Organi } \\
\text { c meat } \\
\left(\mathbf{E}^{1}\right)\end{array}$ & $\begin{array}{l}\text { Meat- } \\
\text { free } \\
\left(\mathbf{E}^{2}\right)\end{array}$ \\
\hline Interviewee & Agronomist & $\begin{array}{c}\text { Quality } \\
\text { Manager }\end{array}$ & $\begin{array}{c}\text { Quality } \\
\text { General } \\
\text { Manager }\end{array}$ & $\begin{array}{c}\text { Marketing \& } \\
\text { Communication } \\
\text { Manager }\end{array}$ & \multicolumn{2}{|c|}{ CEO and owner } \\
\hline $\begin{array}{l}\text { Motivation } \\
\text { for quality } \\
\text { and health }\end{array}$ & $\begin{array}{c}\text { 'The company } \\
\text { pursues a } \\
\text { differentiation } \\
\text { strategy, } \\
\text { focusing on } \\
\text { sustainability as } \\
\text { a means of } \\
\text { quality and } \\
\text { differentiation'. }\end{array}$ & $\begin{array}{l}\text { 'The company } \\
\text { aims at } \\
\text { providing } \\
\text { customers } \\
\text { with high- } \\
\text { quality, value- } \\
\text { added } \\
\text { products, thus } \\
\text { positioning } \\
\text { itself in a } \\
\text { medium-high } \\
\text { segment'. }\end{array}$ & $\begin{array}{l}\text { 'The company } \\
\text { desires to excel } \\
\text { in quality with } \\
\text { regard to both } \\
\text { product and } \\
\text { process, as well } \\
\text { as the } \\
\text { relationship } \\
\text { with the } \\
\text { surrounding } \\
\text { social and } \\
\text { natural } \\
\text { environment'. }\end{array}$ & $\begin{array}{l}\text { 'The group is } \\
\text { striving to } \\
\text { design, develop, } \\
\text { manufacture, } \\
\text { and market } \\
\text { products that } \\
\text { will help } \\
\text { consumers to } \\
\text { achieve a } \\
\text { healthy and } \\
\text { balanced diet'. }\end{array}$ & \multicolumn{2}{|c|}{$\begin{array}{l}\text { 'The company's } \\
\text { main goal is to } \\
\text { pursue a } \\
\text { differentiation } \\
\text { strategy offering } \\
\text { the opportunity to } \\
\text { choose among } \\
\text { different } \\
\text { alternatives } \\
\text { without ignoring } \\
\text { taste, health and } \\
\text { nutritional } \\
\text { properties'. }\end{array}$} \\
\hline
\end{tabular}

Table 1. General information of the cases 


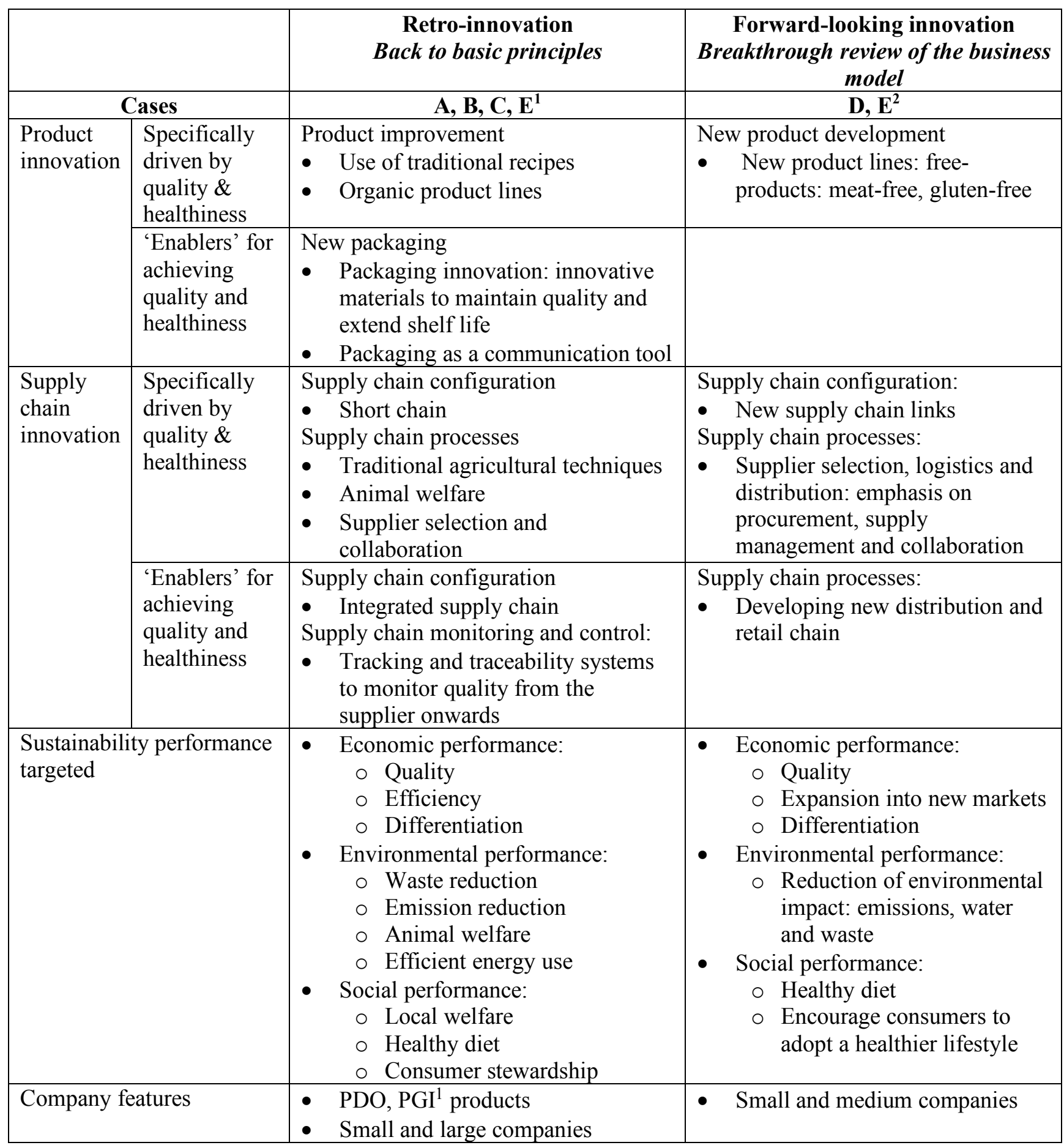

Table 2. Innovation for sustainability: two approaches

\footnotetext{
${ }^{1}$ PDO: Protected designation of origin; PGI: Protected geographical indication. These certified products have specific regulations in terms of origin and production methods (European Commission, 2014).
} 
Author's version of the article: in León-Bravo, V., Moretto, A., Cagliano, R., \& Caniato, F. (2019). “Innovation for sustainable development in the food industry: Retro and forwardlooking innovation approaches to improve quality and healthiness". Published in Corporate Social Responsibility and Environmental Management, 26(5), 1049-1062. DOI:

10.1002/csr.1785

\section{Appendix A. Coding}

\begin{tabular}{|c|c|c|c|c|}
\hline $\begin{array}{c}\text { Type of } \\
\text { innovation }\end{array}$ & $\begin{array}{l}\text { Group of } \\
\text { innovation }\end{array}$ & Item & Description & Reference \\
\hline \multirow[t]{11}{*}{$\begin{array}{l}\text { Supply } \\
\text { Chain }\end{array}$} & \multirow[t]{5}{*}{$\begin{array}{l}\text { Supply chain } \\
\text { configuration }\end{array}$} & Short supply chain & $\begin{array}{l}\text { Configurations for reducing travelling distance and for } \\
\text { ensuring product characteristics, such as freshness, taste and } \\
\text { specific origin }\end{array}$ & \multirow{5}{*}{$\begin{array}{l}\text { Goodman, 2004; } \\
\text { Ilbery \& Maye, 2005; } \\
\text { Maloni \& Brown, } \\
\text { 2006; Beske et al., } \\
2014\end{array}$} \\
\hline & & Virtuous chain & $\begin{array}{l}\text { Configurations that close the loop from seed production to } \\
\text { waste management and recycling, and that reuse sub-products } \\
\text { for fertilizers }\end{array}$ & \\
\hline & & $\begin{array}{l}\text { Integrated supply } \\
\text { chain }\end{array}$ & $\begin{array}{l}\text { Configurations adopting additional operations that facilitate } \\
\text { control and monitoring for ensuring product characteristics }\end{array}$ & \\
\hline & & $\begin{array}{l}\text { Development of new } \\
\text { retail channels }\end{array}$ & New alternative selling channels rather than traditional retail & \\
\hline & & $\begin{array}{l}\text { Development of new } \\
\text { links for new products }\end{array}$ & $\begin{array}{l}\text { Searching, selecting and integrating new actors in the supply } \\
\text { chain to help change the way they do business }\end{array}$ & \\
\hline & \multirow[t]{6}{*}{$\begin{array}{l}\text { Supply chain } \\
\text { processes }\end{array}$} & Production processes & $\begin{array}{l}\text { Cleaner production, eco-efficiency innovations, energy } \\
\text { efficiency innovations and waste handling (e.g. recycling, } \\
\text { disposal, reduced wastewater discharges and improved } \\
\text { sewage control) }\end{array}$ & \multirow{3}{*}{$\begin{array}{l}\text { Catarino et al., 2007; } \\
\text { Pagell \& Wu, 2009; } \\
\text { van der Vorst et al., } \\
\text { 2009; Cassells \& } \\
\text { Lewis, 2011; Zhu et } \\
\text { al., 2012 }\end{array}$} \\
\hline & & $\begin{array}{l}\text { Logistics and } \\
\text { distribution }\end{array}$ & $\begin{array}{l}\text { Efficient transportation networks, transportation modes, } \\
\text { distribution channels, fleet management etc. }\end{array}$ & \\
\hline & & $\begin{array}{l}\text { Agricultural } \\
\text { techniques }\end{array}$ & $\begin{array}{l}\text { Innovative agricultural techniques, incorporating technologic } \\
\text { tools and revising production processes for improving } \\
\text { sustainability }\end{array}$ & \\
\hline & & Animal welfare & $\begin{array}{l}\text { Ensuring that animals do not endure unnecessary suffering; } \\
\text { guaranteeing proper handling, housing, transport and slaughter } \\
\text { as an indicator of food safety and quality }\end{array}$ & $\begin{array}{l}\text { Maloni \& Brown, } \\
2006\end{array}$ \\
\hline & & Supplier selection & $\begin{array}{l}\text { Supplier selection based on sustainability as well as economic } \\
\text { performance }\end{array}$ & Pagell \& Wu, 2009 \\
\hline & & $\begin{array}{l}\text { Supplier collaboration } \\
\text { and development }\end{array}$ & $\begin{array}{l}\text { Relationship between parties to define and develop } \\
\text { environmental and social programs, to build trust and to } \\
\text { establish and/or improve sustainability }\end{array}$ & $\begin{array}{l}\text { Vachon \& Klassen, } \\
\text { 2008; Gold et al., }\end{array}$ \\
\hline
\end{tabular}


Author's version of the article: in León-Bravo, V., Moretto, A., Cagliano, R., \& Caniato, F. (2019). "Innovation for sustainable development in the food industry: Retro and forwardlooking innovation approaches to improve quality and healthiness". Published in Corporate Social Responsibility and Environmental Management, 26(5), 1049-1062. DOI:

\begin{tabular}{|c|c|c|c|c|}
\hline & & & & $\begin{array}{l}2010 ; \text { Beske et al., } \\
2014\end{array}$ \\
\hline & \multirow[t]{3}{*}{$\begin{array}{l}\text { Supply chain } \\
\text { monitoring } \\
\text { and control }\end{array}$} & $\begin{array}{l}\text { Tracking and } \\
\text { traceability systems }\end{array}$ & $\begin{array}{l}\text { Adopting new ways for ensuring traceability and conformity } \\
\text { to expected product standards, e.g. implementing tracking } \\
\text { technology (barcodes and radio frequency identification } \\
\text { (RFID)), }\end{array}$ & \multirow[t]{3}{*}{$\begin{array}{l}\text { Golan et al., 2004; } \\
\text { Beske et al., } 2014\end{array}$} \\
\hline & & $\begin{array}{l}\text { Quality control and } \\
\text { certification }\end{array}$ & $\begin{array}{l}\text { Engage in certification schemes for product or process } \\
\text { sustainability }\end{array}$ & \\
\hline & & Supplier auditing & $\begin{array}{l}\text { Inspection visit in the supplier's plant to check the } \\
\text { sustainability practices }\end{array}$ & \\
\hline \multirow[t]{3}{*}{ Product } & \multicolumn{2}{|c|}{ Product improvement } & $\begin{array}{l}\text { Recover, boost, correct or enhance existing products with the } \\
\text { aim of improving sustainability influenced by quality and } \\
\text { healthiness: e.g. change/adapt product ingredients with } \\
\text { different origins or qualities, change/adapt recipes, adopt } \\
\text { organic ingredients and recover old processes }\end{array}$ & $\begin{array}{l}\text { Bocken et al., 2014; } \\
\text { Klewitz \& Hansen, } \\
2014\end{array}$ \\
\hline & \multicolumn{2}{|c|}{ New product development } & $\begin{array}{l}\text { Create innovative products with new ingredients, new } \\
\text { concepts, new recipes }\end{array}$ & $\begin{array}{l}\text { Earle, 1997; } \\
\text { Appelqvist et al., } \\
2004\end{array}$ \\
\hline & \multicolumn{2}{|c|}{ New packaging } & $\begin{array}{l}\text { Partial or total packaging redesign, use of new packaging } \\
\text { materials or processes }\end{array}$ & $\begin{array}{l}\text { Bocken et al., 2014; } \\
\text { Klewitz \& Hansen, } \\
2014\end{array}$ \\
\hline
\end{tabular}




\section{Appendix B. Cross-case Analysis}

\section{B.1. Supply chain innovations}

\begin{tabular}{|c|c|c|c|c|c|c|c|c|c|}
\hline \multirow[b]{2}{*}{ Case } & \multicolumn{3}{|c|}{ Supply chain configuration } & \multicolumn{3}{|c|}{ Supply chain processes } & \multicolumn{3}{|c|}{ Supply chain monitoring $\&$ control } \\
\hline & $\begin{array}{l}\text { Specifically } \\
\text { driven by } \\
\text { quality \& } \\
\text { healthiness }\end{array}$ & $\begin{array}{c}\text { 'Enablers' } \\
\text { for } \\
\text { achieving } \\
\text { quality \& } \\
\text { healthiness }\end{array}$ & $\begin{array}{c}\text { 'Good to } \\
\text { have' } \\
\text { sustainability } \\
\text { practices }\end{array}$ & $\begin{array}{l}\text { Specifically } \\
\text { driven by } \\
\text { quality \& } \\
\text { healthiness }\end{array}$ & $\begin{array}{c}\text { 'Enablers' } \\
\text { for } \\
\text { achieving } \\
\text { quality \& } \\
\text { healthiness }\end{array}$ & $\begin{array}{l}\text { 'Good to have' } \\
\text { sustainability } \\
\text { practices }\end{array}$ & $\begin{array}{c}\text { Specifically } \\
\text { driven by } \\
\text { quality \& } \\
\text { healthiness }\end{array}$ & $\begin{array}{c}\text { 'Enablers' } \\
\text { for } \\
\text { achieving } \\
\text { quality \& } \\
\text { healthiness }\end{array}$ & $\begin{array}{c}\text { 'Good to } \\
\text { have' } \\
\text { sustainability } \\
\text { practices }\end{array}$ \\
\hline A & $\begin{array}{l}\text { Short SC } \\
\text { Virtuous } \\
\text { chain }\end{array}$ & $\begin{array}{l}\text { Integrated } \\
\mathrm{SC}\end{array}$ & & $\begin{array}{l}\text { Agricultural } \\
\text { techniques }\end{array}$ & & $\begin{array}{l}\text { Environmental } \\
\text { practices: green } \\
\text { energy }\end{array}$ & $\begin{array}{l}\text { Quality } \\
\text { control and } \\
\text { certifications }\end{array}$ & $\begin{array}{l}\text { Tracking and } \\
\text { traceability } \\
\text { systems }\end{array}$ & \\
\hline B & Short SC & $\begin{array}{l}\text { Integrated } \\
\text { SC }\end{array}$ & & $\begin{array}{l}\text { Animal } \\
\text { welfare }\end{array}$ & $\begin{array}{l}\text { Production } \\
\text { and logistics } \\
\text { system to } \\
\text { reduce waste } \\
\end{array}$ & $\begin{array}{l}\text { Environmental } \\
\text { practices: green } \\
\text { energy and waste } \\
\text { management } \\
\end{array}$ & & $\begin{array}{l}\text { Tracking and } \\
\text { traceability } \\
\text { systems }\end{array}$ & \\
\hline $\mathrm{C}$ & $\begin{array}{l}\text { Short SC } \\
\text { for PDO } \\
\text { products }\end{array}$ & & & $\begin{array}{l}\text { Supply } \\
\text { collaboration } \\
\text { and } \\
\text { development }\end{array}$ & & $\begin{array}{l}\text { Environmental } \\
\text { practices: green } \\
\text { energy and waste } \\
\text { management; } \\
\text { Technology } \\
\text { innovation (waste } \\
\text { management) }\end{array}$ & \begin{tabular}{|l} 
Quality \\
control and \\
certifications \\
(origin)
\end{tabular} & & \\
\hline $\mathrm{D}$ & Short SC & & & $\begin{array}{l}\text { Supplier } \\
\text { selection }\end{array}$ & & $\begin{array}{l}\text { Environmental } \\
\text { practices: } \\
\text { waste } \\
\text { management } \\
\end{array}$ & & $\begin{array}{l}\text { Traceability } \\
\text { systems }\end{array}$ & \\
\hline
\end{tabular}


Author's version of the article: in León-Bravo, V., Moretto, A., Cagliano, R., \& Caniato, F. (2019). “Innovation for sustainable development in the food industry: Retro and forwardlooking innovation approaches to improve quality and healthiness". Published in Corporate Social Responsibility and Environmental Management, 26(5), 1049-1062. DOI:

10.1002/csr.1785

\begin{tabular}{|c|l|l|l|l|l|l|}
\hline $\mathrm{E}^{1}$ & Short SC & & $\begin{array}{l}\text { Supplier } \\
\text { selection; } \\
\text { Logistics } \\
\text { and } \\
\text { distribution }\end{array}$ & $\begin{array}{l}\text { Production } \\
\text { process to reduce } \\
\text { energy } \\
\text { consumption; } \\
\text { Environmental } \\
\text { practices: green } \\
\text { energy }\end{array}$ \\
\hline $\mathrm{E}^{2}$ & $\begin{array}{l}\text { New supply } \\
\text { for new } \\
\text { products }\end{array}$ & $\begin{array}{l}\text { Supplier } \\
\text { selection; } \\
\text { Logistics } \\
\text { and } \\
\text { distribution }\end{array}$ & $\begin{array}{l}\text { Develop new } \\
\text { retail } \\
\text { channels }\end{array}$ & $\begin{array}{l}\text { Environmental } \\
\text { practices: green } \\
\text { energy; } \\
\text { Production } \\
\text { process: reduction } \\
\text { of energy } \\
\text { consumption }\end{array}$ \\
\hline
\end{tabular}




\section{B.2 Product innovations}

\begin{tabular}{|c|c|c|c|c|c|c|c|c|c|}
\hline Case & \multicolumn{3}{|c|}{ Product improvement } & \multicolumn{3}{|c|}{ New product development } & \multicolumn{3}{|c|}{ New packaging } \\
\hline A & $\begin{array}{l}\text { Organic } \\
\text { product lines; } \\
\text { Use of } \\
\text { traditional } \\
\text { recipes }\end{array}$ & & & $\begin{array}{l}\text { Development } \\
\text { of new } \\
\text { organic } \\
\text { product lines }\end{array}$ & & & & $\begin{array}{l}\text { Packaging } \\
\text { innovation for } \\
\text { extending shelf } \\
\text { life used as a } \\
\text { communication } \\
\text { tool }\end{array}$ & \\
\hline B & $\begin{array}{l}\text { Organic } \\
\text { product lines; } \\
\text { Use of } \\
\text { traditional } \\
\text { recipes }\end{array}$ & & & & & & & $\begin{array}{l}\text { Packaging } \\
\text { innovation: } \\
\text { innovative } \\
\text { materials to } \\
\text { maintain } \\
\text { quality and to } \\
\text { be used as } \\
\text { communication } \\
\text { tools }\end{array}$ & \\
\hline $\mathrm{C}$ & $\begin{array}{l}\text { Use of } \\
\text { traditional } \\
\text { recipes }\end{array}$ & & & & & & & $\begin{array}{l}\text { Innovative } \\
\text { bottling system }\end{array}$ & $\begin{array}{l}\text { Packing: } \\
\text { technology } \\
\text { innovations }\end{array}$ \\
\hline $\mathrm{D}$ & $\begin{array}{l}\text { Organic } \\
\text { product lines }\end{array}$ & & & $\begin{array}{l}\text { Innovative } \\
\text { product lines: } \\
\text { gluten-free, } \\
\text { lactose-free } \\
\text { and sugar- } \\
\text { free }\end{array}$ & & & & & $\begin{array}{l}\text { Compostable } \\
\text { packaging }\end{array}$ \\
\hline
\end{tabular}


Author's version of the article: in León-Bravo, V., Moretto, A., Cagliano, R., \& Caniato, F. (2019). "Innovation for sustainable development in the food industry: Retro and forwardlooking innovation approaches to improve quality and healthiness". Published in Corporate Social Responsibility and Environmental Management, 26(5), 1049-1062. DOI:

$10.1002 / \mathrm{csr} .1785$

\begin{tabular}{|c|l|l|l|l|l|l|l|}
\hline $\mathrm{E}^{1}$ & $\begin{array}{l}\text { Organic } \\
\text { product lines }\end{array}$ & & & & & $\begin{array}{l}\text { Packaging } \\
\text { innovation for } \\
\text { shelf space }\end{array}$ \\
\hline $\mathrm{E}^{2}$ & & & & $\begin{array}{l}\text { Innovative } \\
\text { product line: } \\
\text { meat-free }\end{array}$ & & & $\begin{array}{l}\text { Packaging } \\
\text { innovation for } \\
\text { shelf space }\end{array}$ \\
\hline
\end{tabular}




\section{Appendix C. Cross-case analysis (sustainability performance)}

\begin{tabular}{|c|c|c|c|}
\hline \multirow[t]{2}{*}{ Case } & \multicolumn{3}{|c|}{ Performance } \\
\hline & Economic & Environmental & Social \\
\hline A & $\begin{array}{l}\text { Improved quality and } \\
\text { efficiency; } \\
\text { Materials' use } \\
\text { optimization; } \\
\text { Savings; } \\
\text { Differentiation }\end{array}$ & $\begin{array}{l}\text { Soil conservation; } \\
\text { Waste reduction; } \\
\text { Reduction of energy consumption; } \\
\text { Reduction of emissions (travelled } \\
\text { distance) }\end{array}$ & $\begin{array}{l}\text { Local welfare; } \\
\text { Healthy diet; } \\
\text { Corporativism and } \\
\text { consumer stewardship }\end{array}$ \\
\hline B & $\begin{array}{l}\text { Improved quality and } \\
\text { efficiency; } \\
\text { Better use of resources; } \\
\text { Differentiation }\end{array}$ & $\begin{array}{l}\text { Use of renewable resources; } \\
\text { Animal welfare; } \\
\text { Waste reduction; } \\
\text { Reduction of emissions (travelled } \\
\text { distance) }\end{array}$ & $\begin{array}{l}\text { Consumer stewardship; } \\
\text { Healthy diet; } \\
\text { Local welfare }\end{array}$ \\
\hline $\mathrm{C}$ & $\begin{array}{l}\text { Improved quality and } \\
\text { efficiency; } \\
\text { Differentiation }\end{array}$ & $\begin{array}{l}\text { Energy saving in building } \\
\text { construction; } \\
\text { Reduction of emissions; } \\
\text { Waste reduction }\end{array}$ & $\begin{array}{l}\text { Promotion of regional } \\
\text { agriculture; } \\
\text { Local welfare }\end{array}$ \\
\hline $\mathrm{D}$ & $\begin{array}{l}\text { Expansion in new market; } \\
\text { Differentiation; } \\
\text { Improved quality }\end{array}$ & $\begin{array}{l}\text { Reducing environmental impact } \\
\text { (emissions, water consumption and } \\
\text { waste) }\end{array}$ & $\begin{array}{l}\text { Care for human health; } \\
\text { Local projects: promotion } \\
\text { of good eating habits, } \\
\text { sports etc. }\end{array}$ \\
\hline$E^{1}$ & $\begin{array}{l}\text { Expansion in new market; } \\
\text { Differentiation; } \\
\text { Improved quality and } \\
\text { efficiency }\end{array}$ & $\begin{array}{l}\text { Reducing environmental impact } \\
\text { (emissions, water consumption and } \\
\text { waste); } \\
\text { Efficient use of energy; } \\
\text { Animal welfare }\end{array}$ & $\begin{array}{l}\text { Employee well-being; } \\
\text { Consumers' healthier } \\
\text { eating habits }\end{array}$ \\
\hline$E^{2}$ & $\begin{array}{l}\text { Expansion in new market: } \\
\text { meat-free; } \\
\text { Differentiation; } \\
\text { Improved quality }\end{array}$ & $\begin{array}{l}\text { Reducing environmental impact } \\
\text { (emissions, water consumption and } \\
\text { waste); } \\
\text { Efficient use of energy }\end{array}$ & $\begin{array}{l}\text { Healthy diet; } \\
\text { Employee well-being; } \\
\text { Consumers' healthier } \\
\text { eating habits }\end{array}$ \\
\hline
\end{tabular}


Author's version of the article: in León-Bravo, V., Moretto, A., Cagliano, R., \& Caniato, F. (2019). "Innovation for sustainable development in the food industry: Retro and forwardlooking innovation approaches to improve quality and healthiness". Published in Corporate Social Responsibility and Environmental Management, 26(5), 1049-1062. DOI:

10.1002/csr.1785

\section{Figure 1: Research Framework}

\begin{tabular}{|c|c|c|c|c|}
\hline $\begin{array}{l}\text { Drivers for Sustainable } \\
\text { Innovation }\end{array}$ & RQ1 & & RQ2 & $\begin{array}{l}\text { Sustainable targeted } \\
\text { performance }\end{array}$ \\
\hline - Healthiness & & $\begin{array}{l}\text { Supply chain innovation } \\
\text { - Product innovation }\end{array}$ & & $\begin{array}{l}\text { - Economic } \\
\text { - Environmental } \\
\text { - Social }\end{array}$ \\
\hline
\end{tabular}

